Ethiopian Journal of Environmental Studies \& Management 10(2): 262 - 275, 2017.

ISSN:1998-0507

Submitted: January 27, 2017

doi: http://dx.doi.org/10.4314/ejesm.v10i2.12

Accepted: March 20, 2017

\title{
ANALYSIS OF POULTRY FARMERS PERCEPTION ON ENVIRONMENTAL ISSUES ASSOCIATED WITH POULTRY FARMING IN KWARA STATE, NIGERIA
}

\author{
*ODUWAIYE, M.O., OGUNLADE, I., OMOTESHO, K.F., OLADIPO, F.O. AND \\ OMOPARIOLA, O.A.
}

Department of Agricultural Extension and Rural Development, University of Ilorin, Ilorin Nigeria

\begin{abstract}
This study examined the poultry farmers perception on environmental issues associated with poultry farming in Kwara State, Nigeria. The specific objectives were to: (i) describe the socio-economic characteristics of the farmers (ii) determine respondents' perceptions of environmental issues associated with poultry farming and (iii) determine the level of farmers' awareness on environmental protection agency's activities. A well-structured questionnaire was used to elicit information from one hundred and twenty five (125) randomly selected commercial poultry farmers from the Poultry Association of Nigeria (PAN), Kwara State Chapter. Data were analyzed using descriptive statistic and Multiple Regression Analysis. Results of analysis showed that mean age of respondents was 45years, average farm size was 1320 birds and average poultry farming experience was 11 years. Also, majority were male (79.2\%), married (83.2\%), and had tertiary education (97.6\%). The perception of farmers on environmental issues was high (mean =3.80) and significantly influenced by farmers' age $(B=0.225, p<0.05)$, level of education $(B=0.178$, $p<0.01)$, farming experience $(B=0.142, p<0.05)$, and farm size $(B=0.177, p<0.05)$. Level of farmers' awareness of the activities of environmental protection agency was low (38.8\%) in the study area. The study concluded that poultry farmers' perception on environmental issues associated with poultry farming was high in the study area. The study recommends among others that this high perception potential could be used as premise by relevant stakeholders or agencies responsible for environmental protection, in providing farmers with appropriate innovations on environmental management and protection.
\end{abstract}

Key Words: Poultry farming, Perception, Environmental issues, Kwara state

\section{Introduction}

Poultry production generally has significantly contributed to the livelihoods of most rural households in developing countries (FAO, 2011). Some problems however associated with rapid growth in poultry industry include the large scale accumulation of poultry wastes including manure and litter which may pose disposal and environmental problems unless environmentally and economically sustainable management technologies are evolved (Bolan et al., 2010). Adewumi et al. (2011) also noted

*Corresponding Author: Oduwaiye, M.O.

Email: muyiwaoduwaiye@yahoo.com 
that large turnout of wastes from poultry encourages the growth of microbes, attracts houseflies, constitutes health hazard to man, animals and thus becomes a menace to the environment.

In Nigeria, the need to preserve the environment against possible harm, pollution and degradation led to the setting up of the Federal Environmental Protection Agency. A regulatory body saddled with the responsibility of protecting and enhancing the environment. The roles of the agency range from management, waste disposal, monitoring pollution, research and development, documentation of environmental data, maintenance, environmental awareness creation and regulation of industrial activities (EPA, 2011).

Omofonmwan and Osa-Edoh (2008), however reported that despite the fact that the agency enjoys legal support and funding from the Nigerian federal government, the height of success since recorded by FEPA is far below her set objectives and goals. This according to them is because the pace at which environmental degradation is occurring is becoming worse than what it used to be before the establishment of the agency.

For the achievement of an environmentally friendly poultry farming operation, a clear understanding of the perception of poultry farmers on the environmental issues associated with commercial poultry farming is a useful first step. The perceptions of farmers about an innovation have been shown to be very closely related to the knowledge they have about it. Perceptions relate to the views farmers hold about an innovation based on their felt needs and prior experiences (Seline et al., 2014). Perceptions have been shown to be good determinants of adoption process (Adesina and Baidu-Forson, 1995). The perception individual holds about an innovation is more relevant in determining his or her passage through the innovation-decision process as well as determining his attitude towards it (Rogers, 1995).

Despite the fact that many studies have been carried out to assess improvement in poultry production over the years, however, no research has been conducted on the perception of commercial poultry farmers on environmental issues related to poultry farming in the study area. Therefore, this study was conducted to assess the poultry farmers' perception on environmental issues associated with poultry farming in Kwara state, Nigeria. The specific objectives were to:

i. describe the socio-economic characteristics of commercial poultry farmers in the study area;

ii. determine the perceptions of commercial poultry farmers on environmental issues associated with poultry farming and;

iii. determine the farmers' level of awareness of the activities of Environmental Protection Agency (EPA) in managing environmental pollution in commercial poultry farms in the study area.

\section{Hypothesis of the Study}

Ho: Socio-economic characteristics of poultry farmers do not influence their perceptions on environmental issues associated with poultry farming.

\section{Methodology}

The study was carried out in Kwara State, Nigeria located between latitudes $7^{\circ} 45^{\prime} \mathrm{N}$ and $9^{\circ} 30^{\prime} \mathrm{N}$ and longitudes $2^{\circ}$ $30^{\prime} \mathrm{E}$ and $6^{\circ} 25^{\prime} \mathrm{E}$. Kwara state has a population of 2.59 million people and total land area of about $36,825 \mathrm{~km}^{2}$, 
(Kwara State, 2010). The climate is intermediate, varying between the extremes of dryness, coolness and hotness. The mean monthly rainfall ranges between $50 \mathrm{~mm}$ during the wettest months and $24 \mathrm{~mm}$ during the driest period. The driest months are from January to March, while the rains last from May to September with occasional drizzles in October. The minimum average temperature throughout the state ranges between $21^{\circ} \mathrm{C}$ while maximum average temperature ranges approximately between $30^{\circ} \mathrm{C}$ and $35^{\circ} \mathrm{C}$ (KWADP, 2000).

The population for this study comprised of all the commercial poultry farmers in Kwara state, Nigeria. Sample frame for the study comprised of the lists of 275 registered commercial poultry farmers obtained from Poultry association of Nigeria (PAN), Kwara state chapter. Fifty percent of the commercial poultry farmers were randomly selected to make a total sample size of 138 respondents for the study. However, of the 138 questionnaires administered to the poultry farmers, only
125 were retrieved, giving a response rate of $90.6 \%$

Data were collected with structured questionnaire and analyzed using descriptive statistics such as frequency counts, percentages and means. The multiple regression analysis was used to test the hypotheses of the study respectively. The choice of this model was based on its proven adequacy in situations when there is the need to predict the value of a variable (the dependent variable) based on the value of two or more other variables called the independent, regressor or predictor variables (Berger, 2003).

The dependent variable is the poultry farmers' perception on environmental issues associated with poultry farming. This was measured using a five point Likert rating scale of Strongly agree $=5$, agree $=4$, undecided $=3$, disagree $=2$, strongly disagree $=1$

The mean score of the respondents was adopted as a measure of their perception on environmental issues. Mean (0.00-2.99) $=$ Low level of perception while mean (3.00 and above) $=$ high level of perception. 
Analysis of Poultry Farmers Perception on Environmental Issues.................DDUWAIYE et al.

\section{Results and Discussion}

Table 1: Socio-economic Characteristics of Commercial Poultry Farmers

\begin{tabular}{llll}
\hline $\begin{array}{l}\text { Socio-economic Characteristics } \\
\text { Gender }\end{array}$ & Frequency & Percentage & Mean \\
Male & 99 & 79.2 & \\
Female & 26 & 20.8 & \\
Age (years) & & & \\
Below 30 & 18 & 14.4 & \\
$30-39$ & 23 & 18.4 & 45.3 \\
$40-49$ & 29 & 23.2 & \\
$50-59$ & 39 & 31.2 & \\
60 and above & 16 & 12.8 & \\
Marital Status & & 16.8 & \\
Single & 21 & 83.2 & \\
Married & 104 & 0.8 & \\
Educational Level & & 0 & \\
No formal education & 1 & 1.6 & \\
Primary education & - & 97.6 & \\
Secondary education & 2 & 79.2 & \\
Tertiary education & 122 & \\
Gender & & \\
Male & 99 & & \\
\hline
\end{tabular}

Results presented in Table 1 show that majority of respondents were male (79.2\%). This indicates that female participation in poultry business in the study area was low. In addition, it may be that poultry farming needs more physical strength which can only be obtained from men. The mean age of respondents was 45.3 years with majority within the age bracket of 50-59 years. This implies that respondents were young and fell within the active age bracket. This age bracket according to FAO (1997), belongs to the economically active population category which is between 25-59 years. Majority of the respondents $(83.2 \%)$ were married. The high percentage of married respondents conforms to Jibowo (1992) study that majority of the adult population of a society consists of married people. Being married will likely ensure availability of family labour for poultry farming.

Most of the respondents $(97.6 \%)$ had tertiary education. This implies that the literacy level of commercial poultry farmers in the study area was very high. This agrees with earlier findings by Ogunlade et al. (2007) that majority of commercial poultry farmers in Kwara state had post-secondary education. This finding also corroborates with earlier report by Mafimisebi et al. (2006) among livestock farmers in South-western Nigeria. This is expected as modern poultry keeping requires people who understand and can apply technical information in the production and management of poultry farms. 


\section{Farm Characteristics of Commercial Poultry farmers}

Table 2: Farm characteristics of commercial poultry farmers

\begin{tabular}{|c|c|c|c|}
\hline \multirow{2}{*}{\multicolumn{4}{|c|}{$\begin{array}{l}\text { Characteristics } \\
\text { Farming Experience (years) }\end{array}$}} \\
\hline & & & \\
\hline Below 5 & 13 & 10.4 & \\
\hline $5-10$ & 48 & 38.4 & \\
\hline $11-15$ & 46 & 36.8 & \\
\hline $16-20$ & 15 & 12 & 10.81 \\
\hline $21-25$ & 3 & 3.2 & \\
\hline \multicolumn{4}{|l|}{ Age of Farm (years) } \\
\hline Below 5 & 23 & 18.4 & \\
\hline $5-10$ & 56 & 44.8 & \\
\hline $11-15$ & 41 & 32.8 & 9.45 \\
\hline $16-20$ & 4 & 3.2 & \\
\hline $21-25$ & 1 & 0.8 & \\
\hline \multicolumn{4}{|l|}{ Farm Size (Number of birds) } \\
\hline $1-999$ & 70 & 56 & \\
\hline 1000-2999 & 42 & 33.6 & 1320 \\
\hline 3000 and above & 13 & 10.4 & \\
\hline \multicolumn{4}{|l|}{ Bird type } \\
\hline Broiler only & 10 & 8.0 & \\
\hline Layers only & 53 & 42.4 & \\
\hline Cockerel only & 6 & 4.8 & \\
\hline Broiler, Layers and Cockerel & 56 & 44.8 & \\
\hline \multicolumn{4}{|l|}{ Management type } \\
\hline Battery cages & 54 & 43.2 & \\
\hline Deep litter & 9 & 7.2 & \\
\hline Both & 62 & 49.2 & \\
\hline \multicolumn{4}{|l|}{ Labour type } \\
\hline Self & 39 & 24.0 & \\
\hline Family & 30 & 31.2 & \\
\hline Hired & 29 & 23.2 & \\
\hline Combination & 27 & 21.6 & \\
\hline \multicolumn{4}{|l|}{ Land Ownership } \\
\hline Rented & 30 & 24 & \\
\hline Leased & 16 & 12.8 & \\
\hline Owned & 79 & 63.2 & \\
\hline $\begin{array}{l}\text { Distance between farm and } \\
\text { neighbour's residence }(\mathrm{km})\end{array}$ & nearest & & 0.48 \\
\hline 1 and below & 115 & 92 & \\
\hline $1.01-2.00$ & 4 & 3.2 & \\
\hline $2.01-3.00$ & 5 & 4.0 & \\
\hline $3.01-4.00$ & 1 & 0.8 & \\
\hline
\end{tabular}

Results from Table 2 show that the mean farming experience of respondents was 10.8 years. This implies that commercial poultry farmers in the study area were fairly young in the enterprise. Results further show that majority $(76.8$ 
$\%$ ) of the farmers had poultry farming as their main occupation. The main types of birds reared were broiler, layer and cockerel $(44.8 \%)$. Both battery and deep litter were the common (49.2\%) systems of management among the commercial poultry farmers in the study area. This result agrees with the findings of Ja'afarFuro and Gabdo (2010) that mixed farming was commonly practiced in poultry farming.

The table further reveals that family labour was the commonest $(31.2 \%)$ type of labour used by the commercial poultry farmers in the study area. This result is similar to that of Koyenikan (2011) who found out that rural poultry farmers in Delta state highly depended on family labour. This result implies that farmers will be able to minimize their production costs so as to maximize their outputs, since family labour most times might not attract any wage.

The average number of birds kept by respondents was 1320 birds. According to Ikheloa and Inedia (2005) poultry farms can be classified based on flock size into small scale (1-999 birds), medium scale (1000-2999 birds) and large scale (3000 birds and above). Hence, commercial poultry farming in the study area could be classified as medium scale. This agrees with the report by Okonkwo and Akubuo (2001) that poultry production in the country was mostly at small-sized level. Furthermore, the average age of farms was 9.45 years. This implies that commercial poultry farms in the study area were still in their growing phase. A higher percentage $(63.2 \%)$ of the respondents owned the land used for poultry farming. This according to Menong et al. (2013) is good for livestock growth and development because farmers' management decisions will not be subjected to the whims and caprices of the land owners.

As shown in Table 2, majority $(92.0 \%)$ of the poultry farms in the study area were located between $0.01 \mathrm{~km}$ to $1.00 \mathrm{~km}$ away from the nearest neighbours' residences, $3.2 \%$ were located between 1.01-2.00 km, $4.0 \%$ were located between $2.01-3.00 \mathrm{~km}$ while the remaining $0.8 \%$ were located between 3.01 and $4.00 \mathrm{~km}$ from the neighbours' residences. The aggregate mean distance was estimated at $0.48 \mathrm{~km}$. This implies that most of the poultry farms in the study area were located very close to human settlement.

Perception of Commercial Poultry Farmers on Environmental Issues Associated with Poultry Farming

Result presented in Table 3 shows that mean score of respondents on perception was 3.80. This indicates a high perception of commercial poultry farmers on environmental issues associated with poultry farming in the study area. In other words, the respondents have good knowledge of both positive and negative of implications of environmental issues associated with poultry farming. This knowledge will go a long way in influencing the farmers' willingness and decision to adopt innovations on environmental management practices, especially innovative measures to counter negative environmental influences on themselves, neighbours and immediate surroundings. 
Table 3: Perception of commercial poultry farmers on environmental issues associated with poultry farming

\begin{tabular}{|c|c|c|c|c|c|c|c|c|c|c|}
\hline \multirow[t]{3}{*}{$\mathbf{S} / \mathbf{n}$} & \multirow[t]{3}{*}{ Environmental Issues } & \multicolumn{5}{|c|}{ Likert Rating } & \multirow{3}{*}{$\begin{array}{l}\text { Mean } \\
\text { score }\end{array}$} & \multirow{3}{*}{$\begin{array}{l}\text { Mean } \\
\text { Rating }\end{array}$} & \multirow{3}{*}{$\begin{array}{l}\text { Std. } \\
\text { Dev. }\end{array}$} & \multirow{3}{*}{ Decision } \\
\hline & & SA & $\mathbf{A}$ & $\mathbf{U}$ & D & SD & & & & \\
\hline & & $\begin{array}{l}\text { Freq. } \\
(\%)\end{array}$ & $\begin{array}{l}\text { Freq. } \\
(\%)\end{array}$ & $\begin{array}{l}\text { Freq. } \\
(\%)\end{array}$ & $\begin{array}{l}\text { Freq. } \\
(\%)\end{array}$ & $\begin{array}{l}\text { Freq. } \\
(\%)\end{array}$ & & & & \\
\hline 1 & $\begin{array}{l}\text { Odour from poultry house produces flies and causes } \\
\text { discomfort to the neighbours. }\end{array}$ & $\begin{array}{l}82 \\
(65.6)\end{array}$ & $\begin{array}{l}41 \\
(32.8)\end{array}$ & $\begin{array}{l}0 \\
(0)\end{array}$ & $\begin{array}{l}0 \\
(0)\end{array}$ & $\begin{array}{l}2 \\
(1.6)\end{array}$ & 4.65 & 1 & 0.480 & High \\
\hline 2 & $\begin{array}{l}\text { Odour from poultry wastes can cause sickness to farmers and } \\
\text { their neighbours }\end{array}$ & $\begin{array}{l}81 \\
(64.8)\end{array}$ & $\begin{array}{l}44 \\
(35.2)\end{array}$ & $\begin{array}{l}0 \\
(0)\end{array}$ & $\begin{array}{l}0 \\
(0)\end{array}$ & $\begin{array}{l}0 \\
(0)\end{array}$ & 4.61 & 3 & 0.659 & High \\
\hline 3 & $\begin{array}{l}\text { Unpleasant odour coming from the animal house can cause } \\
\text { neighbours to vacate the area. }\end{array}$ & $\begin{array}{l}73 \\
(58.4)\end{array}$ & $\begin{array}{l}46 \\
(36.8)\end{array}$ & $\begin{array}{l}2 \\
(1.6)\end{array}$ & $\begin{array}{l}3 \\
(2.4)\end{array}$ & $\begin{array}{l}1 \\
(0.8)\end{array}$ & 4.50 & 5 & 1.642 & High \\
\hline 4 & $\begin{array}{l}\text { Excessive dumping of poultry wastes in water can cause harm } \\
\text { to aquatic life. }\end{array}$ & $\begin{array}{l}24 \\
(19.2)\end{array}$ & $\begin{array}{l}61 \\
(48.8)\end{array}$ & $\begin{array}{l}7 \\
(5.6)\end{array}$ & $\begin{array}{l}11 \\
(8.8)\end{array}$ & $\begin{array}{l}22 \\
(17.6)\end{array}$ & 3.53 & 13 & 1.370 & High \\
\hline 5 & $\begin{array}{l}\text { Offensive odour coming from animal house can cause conflict } \\
\text { between farmers and their neighbours. }\end{array}$ & $\begin{array}{l}65 \\
(52.0)\end{array}$ & $\begin{array}{l}59 \\
(47.2)\end{array}$ & $\begin{array}{l}0 \\
(0)\end{array}$ & $\begin{array}{l}0 \\
(0)\end{array}$ & $\begin{array}{l}1 \\
(0.8)\end{array}$ & 4.50 & 5 & 1.642 & High \\
\hline 6 & $\begin{array}{l}\text { Offensive odour coming from animal house can make } \\
\text { neighbours house unfit for social gathering. }\end{array}$ & $\begin{array}{l}94 \\
(75.2)\end{array}$ & $\begin{array}{l}20 \\
(16.0)\end{array}$ & $\begin{array}{l}6 \\
(4.8)\end{array}$ & $\begin{array}{l}4 \\
(3.2)\end{array}$ & $\begin{array}{l}1 \\
(0.8)\end{array}$ & 4.62 & 2 & 0.791 & High \\
\hline 7 & $\begin{array}{l}\text { Dead birds buried in the ground can decay and contaminate } \\
\text { the ground water. }\end{array}$ & $\begin{array}{l}15 \\
(12.0)\end{array}$ & $\begin{array}{l}90 \\
(72.0)\end{array}$ & $\begin{array}{l}6 \\
(4.8)\end{array}$ & $\begin{array}{l}5 \\
(4.0)\end{array}$ & $\begin{array}{l}9 \\
(7.2)\end{array}$ & 3.78 & 11 & 0.966 & High \\
\hline 8 & $\begin{array}{l}\text { Poultry wastes produce poisonous gases which can cause } \\
\text { respiratory problems to the farmers when continuously } \\
\text { inhaled. }\end{array}$ & $\begin{array}{l}16 \\
(12.8)\end{array}$ & $\begin{array}{l}94 \\
(75.2)\end{array}$ & $\begin{array}{l}7 \\
(5.6)\end{array}$ & $\begin{array}{l}6 \\
(4.8)\end{array}$ & $\begin{array}{l}2 \\
(1.6)\end{array}$ & 3.93 & 7 & 1.434 & High \\
\hline 9 & $\begin{array}{l}\text { Poultry wastes gathered up together in one place can decay } \\
\text { and contaminate the water table and pollute drinking water } \\
\text { nearby. }\end{array}$ & $\begin{array}{l}14 \\
(11.2)\end{array}$ & $\begin{array}{l}91 \\
(72.8)\end{array}$ & $\begin{array}{l}6 \\
(4.8)\end{array}$ & $\begin{array}{l}13 \\
(10.4)\end{array}$ & $\begin{array}{l}1 \\
(0.8)\end{array}$ & 3.83 & 10 & 0.790 & High \\
\hline 10 & $\begin{array}{l}\text { Improper poultry waste disposal invites pests and rodents such } \\
\text { as rats, cochcroaches e.tc which can be vectors or carriers of } \\
\text { diseases. }\end{array}$ & $\begin{array}{l}84 \\
(67.2)\end{array}$ & $\begin{array}{l}35 \\
(28.0)\end{array}$ & $\begin{array}{l}0 \\
(0)\end{array}$ & $\begin{array}{l}0 \\
(0)\end{array}$ & $\begin{array}{l}6 \\
(4.8)\end{array}$ & 4.53 & 4 & 1.653 & High \\
\hline 11 & $\begin{array}{l}\text { Poultry wastes produce gases which contribute to global } \\
\text { warming and climate change. }\end{array}$ & $\begin{array}{l}5 \\
(4.0)\end{array}$ & $\begin{array}{l}37 \\
(29.6)\end{array}$ & $\begin{array}{l}63 \\
(50.4))\end{array}$ & $\begin{array}{l}11 \\
(8.8)\end{array}$ & $\begin{array}{l}9 \\
(7.2)\end{array}$ & 3.14 & 17 & 0.904 & High \\
\hline 12 & $\begin{array}{l}\text { Too much noise from birds kept inside the pen can cause } \\
\text { hearing problems to the farmers. }\end{array}$ & $\begin{array}{l}7 \\
(5.6)\end{array}$ & $\begin{array}{l}50 \\
(40.0)\end{array}$ & $\begin{array}{l}9 \\
(7.2)\end{array}$ & $\begin{array}{l}26 \\
(20.8)\end{array}$ & $\begin{array}{l}33 \\
(26.4)\end{array}$ & 2.78 & 19 & 1.361 & Low \\
\hline 13 & $\begin{array}{l}\text { Unpleasant odour from the poultry house can prevent vehicles } \\
\text { from transporting people to the area. }\end{array}$ & $\begin{array}{l}3 \\
(2.4)\end{array}$ & $\begin{array}{l}18 \\
(14.4)\end{array}$ & $\begin{array}{l}9 \\
(7.2)\end{array}$ & $\begin{array}{l}74 \\
(59.2)\end{array}$ & $\begin{array}{l}21 \\
(16.8)\end{array}$ & 2.86 & 18 & 0.275 & Low \\
\hline 14 & $\begin{array}{l}\text { Too many birds kept together in the pen generate dust which } \\
\text { can cause respiratory problems to the farmer. }\end{array}$ & $\begin{array}{l}12 \\
(9.6)\end{array}$ & $\begin{array}{l}51 \\
(40.8\end{array}$ & $\begin{array}{l}14 \\
(11.2)\end{array}$ & $\begin{array}{l}41 \\
(132)\end{array}$ & $\begin{array}{l}7 \\
(5.6)\end{array}$ & 3.16 & 16 & 1.153 & High \\
\hline
\end{tabular}


15 Too much noise from birds inside the pen can cause disturbance to neighbors leaving nearby.

16 Pesticides used in washing or disinfecting poultry house can cause pollution when they enter surface or ground water.

17 Bad odour coming from poultry house can make house rent low in the area

18 Dust generated during food distribution can cause nose irritation to the farmer.

19 Over application of poultry wastes to the soil can contaminate the soil and make it useless for crop production.

$\begin{array}{lllllllll}6 & 110 & 1 & 5 & 3 & 3.89 & 8 & 1.415 & \text { High } \\ (4.8) & (88.0) & (0.8) & (4.0) & (2.4) & & & & \\ 7 & 68 & 8 & 35 & 7 & 3.26 & 14 & 1.101 & \text { High } \\ (5.6) & (54.4) & (6.4) & (28.0) & (5.6) & & & & \\ 13 & 80 & 13 & 18 & 1 & 3.69 & 12 & 1.346 & \text { High } \\ (10.4) & (64.0) & (10.4) & (14.4) & (0.8) & & & & \\ 30 & 71 & 3 & 19 & 2 & 3.86 & 9 & & \\ (24.0) & (56.8) & (2.4) & (15.2) & (1.6) & & & & \\ 27 & 48 & 3 & 13 & 34 & 3.17 & 15 & & \text { High } \\ (21.6) & (38.4) & (2.4) & (10.4) & (27.2) & & & & \end{array}$

3.80

Mean (X) of respondents' level of agreement with

statements on environmental issues

Note: $\mathrm{SA}=$ Strongly Agree, $\mathrm{A}=$ Agree, $\mathrm{U}=$ Undecided, $\mathrm{D}=$ Disagree, $\mathrm{SD}=$ Strongly Disagree. 1-19 implies highest to lowest rank; Decision rule: Mean (0.00$2.99)=$ Low level of perception while mean $(3.00$ and above $)=$ high level of perception. 
Poultry Farmers' Level Awareness of Environmental Protection Agency

Table 4 shows the distribution of respondents based on their levels awareness of the environmental protection agency in the study area. The table shows that more than half $(50.4 \%)$ of the respondents from the study area indicated they had never heard about Environmental Protection Agency before while only $49.6 \%$ revealed they had heard about the agency. The implication is that the awareness about environmental protection agency was low in the study area. This result further shows that majority $(64.8 \%)$ of the farmers were not aware of environmental laws relating to their poultry farm operations while the minority $(35.2 \%)$ indicated that they were aware. This implies that the level of awareness on environmental law was low as well, among poultry farmers in the study area. Table 4 also reveals the distribution of respondents in the study area based on whether or not Environmental Protection Agency had visited their farms before. The table shows that majority $(74.2 \%)$ of the respondents indicated that Environmental Protection Agency had never visited their farms. This result is not surprising as majority of the farmers had earlier indicated their non-awareness of the environmental protection agency (Table 4). Of those farmers who indicated awareness, only $25.8 \%$ reported that the agency had visited their farms.

Table 4: Distribution of poultry farmers based on awareness of Environmental Protection Agency (EPA) $(n=125)$

\begin{tabular}{lll}
\hline & Frequency & Percentage \\
\hline Farmers' & & \\
Awareness of EPA & 62 & 49.6 \\
\hline Yes & 63 & 50.4 \\
No & & \\
Awareness Environmental Laws & 44 & 35.2 \\
Yes & 81 & 64.8 \\
No & 125 & 100 \\
TOTAL & & \\
Agency's visits to farms in the past & 16 & 25.8 \\
Yes & 46 & 74.2 \\
No & 62 & 100 \\
TOTAL & & \\
\hline
\end{tabular}

Farmers' Level of Awareness of Environmental Protection Agency (EPA) Activities in Managing Poultry Farm Environmental Pollution

Table 5 shows the distribution of respondents based on their awareness of the activities of environmental protection agency in managing poultry farm environmental pollution in the study area.
The table shows that issuing of warning notice to farmers due to public complaints on pollution (62.9\%) and arresting and prosecuting environmental law offenders $(61.3 \%)$ were the major activities they were aware the environmental protection agency performs as relating to managing environmental pollution in the study area. 
This result implies that issuing of warning notices to farmers due to public complaints on pollution and arrest and prosecution of environmental law offenders were the common duties performed by this agency in the study area.

Other activities such as enforcement of environmental law (39.2\%), conducting environmental awareness campaign $(24.2 \%)$, provision of waste disposal facilities to farmers (37.1\%), provision of advisory services to farmers on environmental issues (25.8\%), education of poultry farmers on waste disposal $(29.0 \%)$, inspection of poultry houses $(48.4 \%)$, provision of waste collection services $(32.3 \%)$, monitoring poultry waste disposal $(46.7 \%)$ and monitoring and survey of water, air, land and soil in case of pollution (19.4\%) respectively were indicated by the farmers as activities they were less aware of that this agency performs as relating to managing environmental pollution in the study area. The low indication of awareness on environmental law enforcement, monitoring poultry waste disposal and monitoring and survey of water, air, land and soil in case of pollution among respondents implies that Environmental Protection Agency in the study area needs to put in more efforts to the management of poultry environmental pollution among other responsibilities.

Table 5: Farmers' awareness of activities performed by Environmental Protection Agency in managing environmental pollution $(n=62)$

\begin{tabular}{lcc}
\hline Activities of Environmental Protection Agency & Aware & Not Aware \\
\cline { 2 - 3 } & Freq $(\%)$ & Freq (\%) \\
\hline Enforcement of environmental laws & $24(39.2)$ & $38(60.8)$ \\
Arresting and prosecuting environmental law offenders & $38(61.3)$ & $24(28.7)$ \\
Conducting environmental awareness campaign & $15(24.2)$ & $47(75.8)$ \\
Issuing of warning notice to farmers due to public complaints on & $39(62.9)$ & $23(37.1)$ \\
pollution. & & \\
Provision of waste disposal facilities to farmers & $23(37.1)$ & $39(62.3)$ \\
Provision of advisory services to farmers on environmental & $16(25.8)$ & $46(74.2)$ \\
issues. & & \\
Education of poultry farmers on waste disposal & $18(29.0)$ & $44(71.0)$ \\
Inspection of poultry houses & $30(48.4)$ & $32(51.6)$ \\
Provision of waste collection services & $20(32.3)$ & $42(67.7)$ \\
Monitoring poultry waste disposal & $29(46.7)$ & $33(53.3)$ \\
Monitoring and survey of water, air, land and soil in case of & $12(19.4)$ & $50(80.6)$ \\
Pollution. & & \\
Mean(\%) & 38.8 & \\
\hline
\end{tabular}

\section{Hypothesis Testing}

The multiple regression model was fitted to investigate the relationship between selected socio-economic characteristics of farmers and their perception on environmental issues associated with poultry farming. Table 6 reveals that five of the eleven variables had significant regression weights and therefore predicted levels of perception among the respondents of environmental issues.

The variables that contributed to the regression model are the respondents 
'age, farming experience, education status, farm size and distance between farm and neighbours' residence. The age of the poultry farmers positively influenced their perception at $p<0.05$ level of significance. This implies that as the farmer's age increases, his perception on environmental issues increases. The experience of the aged farmers may be responsible for this high perception among them. This may be as a result of the high percentage of respondents above 50 years as indicated in table 1. This takes the presumption that as farmers get older they acquire more experience which will in turn increase their perception. This attribute according to Olumba and Rahji (2014) can be tapped to improve the respondents' farming prowess, thereby increasing their capacity to adopt innovations, especially on environmental management.

At $\mathrm{p}<0.1$, the level of education positively influenced farmers' perception on environmental issues. This means that the higher the level of education, the higher their perception. Education has been linked to widen intellectual horizon, awareness, exposure, and to predispose farmers to new ideas. It is therefore understandable from this result that the more educated the farmers are, the higher their perception. At $p<0.05$, years of farming experience was also found to positively influence farmers' perception on environmental issues. This implies that as the farming experiences of poultry farmers increase, the higher their perception on environmental issues. This may be expected as the experienced poultry farmers must have acquired enough knowledge and awareness of the implications of these environmental issues over the years.

At $\mathrm{p}<0.05, \quad$ perception on environmental issues among commercial poultry farmers in the study area increases as the farm size increases. This could be expected as increase in farm size is likely to increase the farmer's level of waste generation. The higher the waste generated from farm, the higher the tendency for ensuing environmental issues. It is therefore understandable from this study, that the higher the farm size, the higher their perception.

At $\mathrm{p}<0.05$, distance between farm and the neighbour's residence had significant negative influence on the perception of farmers. This means that as the distance of the farm to the neighbour's residence reduces, the higher their perception on environmental issues. This is probably due to the fact that, the shorter the distance of the farm to the neighbour's residence, the greater the environmental pollution effects the farm might likely cause to the residing neighbours, hence the high perception.

Thus Ho is rejected. There is significant relationship between the selected socio- economic characteristics of respondents and their perception on environmental issues associated with poultry farming. 
Table 6: Result of the multiple regression in investigating the socio- economic determinants of the perception of commercial poultry farmers in the study area

\begin{tabular}{|c|c|c|c|c|}
\hline & \multicolumn{3}{|c|}{ Unstandardized Coeffeicients } & \multirow[b]{2}{*}{$\mathrm{p}$-Value } \\
\hline Variables & $\beta$ & Std. Error & $\mathrm{t}$ & \\
\hline (Constant) & & .361 & 10.687 & .000 \\
\hline Gender & .011 & .005 & .164 & .870 \\
\hline Age & $.225^{* *}$ & .067 & 2.715 & .008 \\
\hline Education Status & $.178^{*}$ & .021 & 2.640 & .007 \\
\hline Main occupation & .042 & .078 & .609 & .543 \\
\hline Farming Experience & $.142 * *$ & .082 & 2.282 & .023 \\
\hline Farm size & $.177 * *$ & .000 & 2.629 & .009 \\
\hline Bird type & -.297 & .042 & -4.495 & .000 \\
\hline Management type & .075 & .040 & 1.062 & .289 \\
\hline Labour type & .066 & .032 & .940 & .348 \\
\hline Land ownership & -.078 & .039 & -1.209 & .228 \\
\hline $\begin{array}{l}\text { Distance between farms and } \\
\text { neighbours' residences } \\
\mathrm{R}^{2}=0.164\end{array}$ & $-.168 * *$ & .000 & -2.532 & .012 \\
\hline
\end{tabular}

Significant at $1 \%$ (2-tailed) $* *$ Significant at 5\% (2-tailed)

\section{Conclusion}

Based on the findings in the study, it was concluded that perception of commercial poultry farmers in Kwara state on environmental issues associated with poultry farming was high and tested to be significantly influenced by their level of education, poultry farming experience, size of poultry farm and distance between farm and neighbour's residence. Secondly, level of farmers' awareness of the activities of environmental protection agency in managing pollution from poultry farms was low in the study area.

\section{Recommendations}

The study therefore recommends that:

- The high perception potential of the respondents on environmental issues associated with poultry farming could be used as premise by all relevant stakeholders or agencies responsible for environmental protection in providing farmers with appropriate innovations on environmental management and protection.

- The positive significant effect of education and farming experience on the farmers' perceptions could also be used as a premise in providing the farmers with education / enlightenment workshops needed to offer information and also increase their knowledge in handling environmental challenges relating to commercial poultry farming.

- Greater sensitization about environmental protection agency activities should be provided to the farmers and there should be improvement in environmental pollution control awareness campaigns among commercial poultry farms in the study area. 


\section{References}

Adesina, A.A. and Baidu- Forson, J. (1995). Farmers' perceptions and adoption of new agricultural technology: evidence from analysis in Burkina Faso and Guinea, West Africa. Agricultural Economics, 13: (1): 1-9.

Adewumi, A.A., Adewumi, I.K. and Olaleye, V.F. (2011). Livestock waste-menace: Fish wealth solution. African Journal of Environmental Science and Technology, 5(3):149-154.

Berger, D.E (2003). Introduction to Multiple Regression. Claremont Graduate University. Retrieved from http: wise.cgu.edu on $2^{\text {nd }}$ May, 2014.

Bolan, N.S., Szogi, A.A., Chuasavathi, T., Seshadri, B., Rothrock, Jr. M.J. and Panneerselvam, P. (2010). Uses and management of poultry litter. Centre for Environmental Risk Assessment and Remediation. University of South Australia. World's Poult. Sci. J. 66(4): 673698.

Environment Protection Agency (2011). Available at http://www.environmentagency.gov.uk/

FAO (1997). Current World Fertilizer Situation and Outlook 1994/952000/2001. FAO/UNIDO/World bank Working Group on fertilizers. Rome.

FAO (2011). Importance-of-small-scaleand-semi-commercial poultryproduction-in-developingcountries/.http://www.poultryhub.or g/most-popular/

Ikheloa, E.E. and Inedia, G. (2005). "Analysis of Survival Rate of
Chicks in Poultry Farms in Edo State Nigeria" (eds) Proceedings of $39^{\text {th }}$ Annual Conference of the Agricultural Society of Nigeria, University of Benin, Benin City, Nigeria, October 9th-13th 2005. Pp 43-47.

Ja'afar-Furo, M.R. and Gabdo, B.H. (2010). Identifying major factors of poultry production as

sustainable enterprise among farmers using improved methods in rural Nigeria. Int. J. Poult. Sci., 9: 459- 463.

Koyenikan, M.J. (2011). Extension Workers $^{\text {ce }}$ Access to Climate Information and Sources in Edo State, Nigeria. Scholars Research Library Archives of applied science research, 2011, 3 (4):11-20 Available at http://scholarsresearchlibrary.com/ archive.html Accessed on 20th October 2012

KWADP. (2000). Kwara State Agricultural Development Project Annual Report, pp. 3-7.

Kwara State (2010). Kwara state Government. Available from Kwara state.gov.ng.

Jibowo, A.A. (1992). Essentials of Rural Sociology. Abeokuta: Gbemi Sodipo Press Ltd.

Mafimisebi, T.E., Onyeka, U.P., Ayinde, I.A. and Ashaolu, O.F. (2006). Analysis of Farmer specific socioeconomic determinants of adoption of modern livestock management technologies by farmers in Southwest Nigeria. Journal of Food, Agriculture and Environment, 4: 183-186.

Menong, J.M., Mabe, L.K. and Oladele, O.I. (2013). Analysis of Extension Needs of Commercial Farmers in 
Analysis of Poultry Farmers Perception on Environmental Issues.................0DUWAIYE et al.

North-West Province, South Africa.

J Hum Ecol, 44(2): 139-147 (2013).

Ogunlade, I. Omokanye, C.G. and Adeniji, A.A. (2007). An Assessment of Farmers' Interest in University of Ilorin Poultry Research Results. International Journal of Poultry Science 6(4): 283-288.

Okonkwo, W.I. and Akubuo, C.O. (2001). Thermal analysis and evaluation of heat requirement of a passive solar energy poultry chick brooder in Nigeria. Journal of Renewal Energy, 9: 1

Olumba, C.C. and Rahji, M.A.Y. (2014). An Analysis of the Determinants of the Adoption of Improved Plantain Technologies in Anambra State, Nigeria. Journal of Agriculture and
Sustainability 5: 232-245. ISSN 2201-4357

Omofonmwan, S.I. and Osa-Edoh, G.I. (2008). The Challenges of Environmental Problems in Nigeria. Journal of Human Ecology, 23(1): 53-57.

Rogers, E. (1995). Diffusion of Innovations. New York: Free Press.

Seline, S., Delia, C., Oluyede, C., Gudeta, W. and Maarten, N. (2014). The role of knowledge, attitudes and perceptions in the uptake of agricultural and agroforestry innovations among smallholder farmers in sub- Saharan Africa. International Journal of Agricultural Sustainability: http://www.tandfonline.com/loi/tag $\underline{\mathrm{s} 20}$ 